\title{
Muslim identity in the conceptual field of modern religious studies
}

\author{
Jade Zuriet, Svetlana Lyausheva* \\ Adygea State University, Maykop, 385000, Russia
}

\begin{abstract}
The article justifies the need for an integrated approach to the study of Muslim identity in the conceptual and categorical field of modern religious studies. Various conceptual approaches to the analysis of religious identity are considered. The authors analyze the features of a Muslim identity, the development of which is influenced by transforming religious institutions and crisis phenomena in Islam at present. Muslim identification is one of the main mechanisms of socialization by the individual's recognition of their belonging to the Islamic religion and gaining value orientations of Islam. Muslim identity dramatically changes its configuration and demonstrates both integration and disintegration potential. The conclusion is that the Muslim identity is combined with other levels of identity on the principle of complementarities and has its own specific features.
\end{abstract}

\section{Introduction}

The modern multi-polar world needs a new identification model, which would act as a constructive response to the challenges of globalization and enrich the multicultural and multiconfessional space of Russia. That is why the study of Muslim identity as the challenges of our time acquires exceptional significance.

In modern conditions, the identity structure has undergone greater erosion, losing its homogeneity, stability and integrity. Moreover, the content of one or another of its components is constantly being modified. The transformation of the principles of self-identification leads to a change in the identity of the whole society, the tendency to complicate the identity leads to the spread of the multi-level identity practice. Awareness and acceptance by an individual of any identity carries a certain risk, especially if it is associated with a religious sphere. Among the causes of tension and conflict on the basis of inter-religious and intra-religious relations in Russia, is Muslim identity. The priority area for the study of Muslim identity is its study as a type of religious identity.

When considering Muslim identity in the conceptual field of modern religious studies, the essence of religious identity should first be understood. In this context, the urgent problem is the ratio of different types and levels of identity - ethnic, religious, civil, national, gender, age, etc. At different periods of the development of an individual or group, in different cultural and historical conditions, within the framework of one or another dominant political doctrine, or under

\footnotetext{
*Corresponding author: slyausheva@list.ru
} 
the influence of certain life situations, religious identity is actualized, while other levels of identity are suppressed or subordinated.

\section{Conceptual approaches to the analysis of religious identity}

In the modern world, religion is no longer just a private affair of a particular person, it becomes an element of public space. Defining the forms of publicity of religion, M. Mchedlova notes: "From constructive, related to charity and social ministry, to religious extremism, from the revival of the moral authority of religion and its organizations to the increasing role of the latter as subjects of political goal-setting" (Mchedlova, 2016).

Considering identity as a multi-level and complex structural phenomenon, the authors of this article investigated the relationship of ethnic, regional, civic and religious identities in a multiethnic and multi-confessional region. At the same time, we proceeded from their multilevelness at the personal and group level, the simultaneous inclusion of the individual in the ethnic, regional, civil and religious community, considering self-identification as the basis of social identities (Russian Identity ..., 2010).

In modern Russian religious studies, there are various approaches to the definition of religious identity. Traditionally, religious identity is understood as a person's commitment to a religion, confirmed by subjective self-esteem (self-image as a believer and self-identification with the followers of this religion) and objective evidence (conformity of beliefs and actions with doctrinal rules, regulations of ritual behavior and the norms of everyday life adopted in a particular religious community) (Smirnov, 2011). Religious identity is also presented as the result of selfidentification of a person or reference community with a particular religious teaching or part of it (Mchedlova, 2017).

Comparing religious identity with ethno-confessional identity, S. Ryzhova defines the former as more personal, private, which "is directly related to moral unity and in the worldview sense reflects the personal relationship of the believer with God" (Ryzhova, 2019).

In our opinion, religious identity can be defined as a category of modern religious studies, the content of which is awareness of involvement in religious ideas and values, as well as awareness of belonging to a specific form of religion and religious group. As we see, in addition to the general religious self-determination of a person, we are talking about a specific form of religious affiliation. The key content of religious identity is spiritual orientation, its awareness and correlation with another form of spirituality.

Analyzing the process of the religious identity development, we turn to the studies of D. ErvieLeger, who identifies four aspects of religious identification. Firstly, a community containing social markers and symbols that separate people belonging and not belonging to a particular religion. Secondly, religious ethics may be an aspect of identification. This dimension often emphasizes the feeling that people are inspired, for example, by the Christian ethics of compassion for the weak and poor, or human dignity. Thirdly, a culture that is understood in its general meaning and includes traditions, symbols, practice, doctrines, books, ritual codes, history, everyday life, morality, art, aesthetics and many other cultural aspects. Fourth comes the emotional aspect. To illustrate the author cites religious holidays or events when people feel their community. These may be traditional services for Christmas or Easter; for many, this is an occasion to attend church at least once or twice a year (Hervieu-Leger, 1999). Based on this, we note that religious identity is a form of self-consciousness, built on the awareness of one's belonging to a particular religion and forming its ideas through appropriate religious dogmas.

\section{Methods of researching religious identity}


The methodological search in the study is carried out within the framework of the following approaches: interdisciplinary, systemic, structural and functional. An interdisciplinary approach allows expanding the study of Muslim identity through a typological analysis of multi-level identity; a comparative analysis of existing models of the relationship of various types and types of identity, as understood by modern philosophy of religion; causal analysis of causal relationships, the causes of the emergence and evolution of various processes and phenomena of modern Islam. A systematic approach is necessary to consider Muslim identity in the context of socio-philosophical problems that determine the development of society and culture, under the influence of globalization. The structural-functional approach allows isolating individual elements of religion (the number of believers, ideological, socio-economic, socio-cultural and other resources), the functioning of which determines the development of the Muslim identity.

Also productive from the point of view of an objective study of Muslim identity is the use of patterns of identity formation and structure along the axis of self-identity and we-identity, primordial and constructed components (S. Huntington, Z. Bauman).

Muslim identity: semantic content and polysemy of the term. As we noted earlier, the typology of religious identity can be based on the degree of severity and intensity of religious-worldview certainty: from low and weakly expressed to intolerant, fanatical and radical. A variety of this level of identity is Muslim (Islamic), which is the most risky for multi-ethnic and multi-religious Russia (Jade, 2019). In this point of view, "Muslim identity" and "Islamic identity" are identical concepts.

It should be noted that the influence of the Islamic factor on the multi-level identification process has only recently begun to attract the attention of researchers (Lyausheva, 2018). In the contemporary discourse, the construction of "Muslim identity" is used to a limited extent, and in most works the content of the category itself remains unclear, there is no unambiguous point of view on the substantial components of Muslim identity.

In recent years, Russian scholars have made efforts to conceptualize Muslim identity as a category of religious studies. In their works, S. Kashaf, A. Krylov, M. Mchedlova, R. Rakhmatulin explore various aspects of the role of the Islamic worldview in the structures of social and political identity of citizens. These authors formed a theoretical and methodological understanding of the basic structures of identity and the specifics of their ranking in the process of socio-political identification of Muslims in various specific situations.

The debate about the challenges of Muslim identity has swept most of the regions of Russia and the CIS countries. So, E. Arutyunova, A. Bogomolov, R. Borisov, G. Guzelbaeva, T. Kozyrev, A. Mikhaleva, R. Musina, O. Pavlova, G. Sabirova and several other authors analyze modern trends in the development of Muslim identity. According to these authors, the issue of the specificity of Islamic identity in certain regions is directly related to the problem of the ratio of doctrinal and regional Islam. A little distracted from the given problem, we note that modern Russian Islam is represented by many ethnic groups professing it. Each region where Muslims live has its own specificity of religious practices; in addition, the degree of Muslim involvement in Islamic practice varies. Representatives of Russian Muslim ethnic groups have different attitudes to the structure of social identity, in particular in the context of the relationship between ethnic and religious identity.

A number of works are devoted to one of the main subjects of discussion in the XXI century. - the identity of Muslims living in the countries of the European Union. The development of information technology significantly affects almost all spheres of life of each state and the citizens living in it. An important task in the process of introducing to new opportunities, whether of an individual, a religious community, civilization groups, is the adaptation of their special qualities, or identities, to a society with other moral and cultural values. Despite the fact that European countries such as Great Britain, France and Germany are stable states both politically and economically, the problems of identity are worrying for modern Europeans, and their concern is 
compounded by the constant flow of migrants seeking to preserve their distinctive features and, before total religious identity (Thor, 2014).

In the logic of the identity approach, a clash of worldviews that is difficult for Muslims to avoid in post-industrial societies in Europe leads to the emergence of a hybrid identity. In the matrix of such an identity (for example, a British citizen, Pakistani by birth, Muslim by religion), new social forms (combinations of values, attitudes, preferences, factors) do not replace the old ones, but connect with them being rethought (Henkin, 2015).

Based on the foregoing, we can talk about a combination of factors that made religious scholars include a Muslim identity in their scientific interests. The ambiguity of the category of Muslim identity is explained by the complexity of its genesis. It seems that of particular importance is the problem of the conceptualization of Muslim identity. We share the conceptual judgments of I. Kudryashova, who believes that a Muslim identity is not identical to an Islamic one. Muslim identity, like any other, is not a static phenomenon and it is subject to change, since it is in the sphere of interfaith relations that religious norms and behavioral patterns are modified (Kudryashova, 2017). G. Sabirova considers "Muslimness" as a combination of qualities through articulation or living which reproduces belonging to the Islamic tradition (Sabirova, 2008). S. Nunuev is talking about Islamic identity, which, in his opinion, has become the basis of group solidarity and mobilization, political positioning (Nunuev, 2015).

Muslim identity, in our opinion, is a kind of religious identity, the formation of which can be influenced by religious institutions, organizations, associations. It should be considered as an individual's recognition of his belonging to the Islamic religion and its values. Muslim identification is one of the main mechanisms of socialization through the acquisition of the value of Islam by a person. In our opinion, the main criterion of Muslim identity is the recognition of the values and norms declared by the Koran. It is this circumstance that makes it possible to classify a person as a single member of the social community of Muslims - the Ummah.

\section{Spiritual self-determination}

Muslim identity as a concentrated expression of the Muslim worldview is acquired not only in the course of personal spiritual self-determination, but also under the influence of significant external factors, which include the state of religious life of the surrounding society, changes in the socio-cultural environment, and the circumstances of the socialization of a Muslim. Significant in the process of Muslims' self-identification is the fact that they have an idea about the importance and necessity of preserving their religious identity. The desire of Muslims to preserve their identity is a stumbling block in the settlement of disputes regarding Islamic traditions (Karabulatova, 2017).

In a multi-ethnic society, Muslim identity can be combined according to the principle of complementarity with other levels of identity (ethnic, regional, civic, national, gender and age, social status, professional, etc.). This type of identity implies the ability of believers to respond adequately to the expectations of people interacting with them according to patterns and norms of behavior accepted in Islam. In order to preserve the Muslim identity, a stable relationship is maintained with a religious organization (visiting a mosque, communicating with ministers of Muslim worship and other believers), the lifestyle is brought into compliance with the mandatory requirements that a Muslim must perform daily and throughout his life, must be based on the legal principles of Islam and governed by Sharia (a system of laws governing religious, statepolitical, legal, property, family and marriage, personal life of Muslims).

An important place in the scientific debate is occupied by the problem of identity crisis. In this context, it should be emphasized that the crisis of personality identity is often associated with the crises in society. As noted above, the loss of identity in one medium suggests its search in another. A crisis of Muslim identity, which should be regarded as a reappraisal of Islamic values, is possible with changes in the socio-cultural environment that entail the destruction of existing 
religious institutions of Islam and, as a result, affect the worldview of Muslims, causing loss of confidence in the previous religious system, alienation from it and the search for a new identity. Since the Muslim identity has significant mobilization potential, and groups belonging to the Russian Ummah live quite compactly, it is not difficult to foresee the contours of possible polarization and disintegration (Lyausheva, 2018).

A Muslim identity, experiencing various external and internal influences, can radically change its configuration and have different potentials: from integration to disintegration. Given such realities of modern society as "Islamic extremism" and "Islamic radicalism," it should be emphasized that Islam can be, on the one hand, constructive and, on the other hand, a destructive phenomenon. In our opinion, its constructiveness and destructiveness is determined by the specificity of Islamic identity, which can be either positive ("safe") or deformed ("dangerous").

According to R. Rakhmatulin, a false interpretation of this concept content in a non-Muslim environment, as well as in the case of Muslims' self-identification, is one of the causes of conflicts that arise on a confessional basis and often have political consequences. The problems of determining markers of Muslim identity are associated with differences in the interpretation of Islamic norms that arise mainly in translations of the Koran; with ignorance of these norms or their free interpretation on the part of people who identify themselves as Muslims; with the existence of the Sunnah as the source of Islam, containing many unreliable hadiths that arose as a result of falsification; with the "creativity" of individual clerics who come up with new norms of Muslim identity in their interests (Rakhmatulin, 2018).

In some countries, religious identity prevails over ethnic and national-state identities, despite the fact that in the Islamic world there are a number of other stable supranational identities. Examples of adapting Islamic religion to specific regional conditions, depending on confessional affiliation, include brands such as Russian Islam, Euro-Islam, Turkish Islam, etc.

The risks of Muslim identity include the division into Sunni and Shiite branches; allocation of large regional blocs: Arab Islam, Indo-Iranian Islam, Turkish Islam, North Caucasian Islam, European Islam, Indonesian Islam; the identification of different types of countries with a Muslim population (countries with a dominant traditional Islamic population, countries with a traditional Islamic minority, countries with a migrant Islamic minority) (Perepelkin, 2013). The situation in Russia is complicated by the fact that in the context of modern ethno-cultural communication systems in the North Caucasus, religious doctrine is politicized and its canons are distorted by extremist groups in an effort to create fertile ground for the ideas of the banned in Russia Islamic State (Karabulatova, 2016).

\section{Conclusion}

In the conditions of an unstable world order, the problems of religious identity are being actualized: criteria and types, factors of development and construction. In recent years, the question of the self-identification of Muslims has become especially acute. The very understanding of Muslim identity is being transformed along with the socio-cultural conditions of the existence of Muslims. The appeal of Russian religious science to the concept of Muslim identity is associated with the increasing role of the Islamic factor in the political life of modern states. It also provides an opportunity to assess the characteristics of the political behavior of Muslims, which is ambiguously manifested in modern conditions, when religious extremism has become one of the main problems of mankind. In this regard, particular attention should be paid to the conceptual analysis of the challenges of Islamic "awakening" and the characteristics of Muslim identity.

The process of self-identification of a person undergoes significant changes, which is reflected in the concept of "Muslim identity", which is difficult to operationalize from an academic point of view. This concept has no categorical clarity; an integrated approach is required to understand this phenomenon. The problematic issues of this field of knowledge, in our opinion, are still not 
well defined, the conceptual apparatus is at the stage of development, and the main areas of research require comprehensive study and discussion in the field of modern religious studies.

This article was prepared with the financial support of the Grants Council of the President of the Russian Federation to support leading scientific schools NSh-6738.2018.6 "Islam in the regional socio-cultural space of Russia: diagnosis of the state and transformations (using the example of the Republic of Adygea)".

\section{References}

1. D. Hervieu-Leger, Le pelerin et le converti. La religion en mouvemen (Paris, 1999).

2. I. Karabulatova, M. Polekhina, S. Lyausheva, N. Dubinina, How the discourse of Sufism became the expressive discourse of Islamic radicalism in the regions of "popular Islam" in Russia, Central Asia and the Caucasus, 18 (4) (2017).

3. I. Karabulatova, Ethno-cultural communication Systems in the Northern Caucasus and the Problem of Radical Islam, Central Asia and the Caucasus, 17 (4) (2016).

4. S. Lyausheva, I. Karabulatova, Z. Zhade, N. Ilyinova, The islamic Ummah of Russia and ISIS: Islamic radicalism in the turkic-speaking regions, Central Asia and the Caucasus, 19 (1) (2018).

5. Z.A. Jade, T.M. Kumpilov, Muslim identity as a scientific category, Bulletin of the Adygea State University, Series "Regional Studies: Philosophy, History, Sociology, Jurisprudence, Political Science, Cultural Studies",1, 79-88 (2019).

6. I.V. Kudryashova, Muslim political identity in the modern era: a sacred text and social experience, Bulletin of the RUDN University, Series: Political Science, 19 (4), 349-365 (2017). DOI: 10.22363 / 2313-1438-2017-19-4-349-365

7. M.M. Mchedlova, Socio-cultural meanings of politics: the new logic of interpretation and $\begin{array}{lllll}\text { religious references, Policy, 1, 157-174 (2016). } & \end{array}$ https://doi.org/10.17976/jpps/2016.01.11

8. M.M. Mchedlova, Religious and confessional identity. Identity: Personality, society, politics. Encyclopedic Edition (Publishing house "The World", Moscow, 2017).

9. S.M. Nunuev, Risks of politicization of Islamic identity in modern Russia (based on materials from the North Caucasus), Historical and socio-educational thought, 7 (2), 63-69 (2015).

10. L.S. Perepelkin, Muslim identity in a theoretical context, (2013).

11. R.Yu. Rakhmatulin, Muslim identity issues, Herald of the VEGU, 2, 72-82 (2018).

12. Z. Jade, E. Kukva, S. Liaushev, A. Shadzhe, Russian Identity in the North Caucasus, (Social and humanitarian knowledge; Maykop, LLC "Quality", Moscow, 2010).

13. S.V. Ryzhova, Religiosity, ethno-confessional identity and problems of interethnic harmony, Sociological research, 2, 49-58 (2019). DOI: 10.31857 / S013216250004006-9

14. G.A. Sabirova, Muslim identities, generations and the discursive tradition of Islam in postSoviet Russia. Traditions and innovations in modern Russia. Sociological analysis of interaction and dynamics (ROSSPEN, Moscow, 2008).

15. M.Yu. Smirnov, Sociology of Religion: Dictionary (Publishing House of St. Petersburg. unthat, $\mathrm{SPb}, 2011)$.

16. V.V. Thor, British Muslim identity in the context of multiculturalism, (Philosophy and culture), 1, 89-98 (2014). DOI: 10.7256 / 1999-2793.2014.1.9815

17. S.M. Khenkin, I.V. Kudryashova, The integration of Muslims in Europe: a political aspect, Policy, 2, 137-155 (2015). DOI: https: //doi.org/10.17976/jpps/2015.02.09 